\title{
Pendamping desa (village mentor) as a community manager: a case study of the role of pendamping desa in empowering community and local institution through communication approach in the province of Riau, Indonesia
}

\author{
Antar Venus $^{1, *}$, Adiatma Siregar ${ }^{2}$ \\ ${ }^{1}$ Department of Communication Management, Faculty of Communication, Padjadjaran University \\ ${ }^{2}$ Department of Economics, Faculty of Economics and Business, Padjadjaran University \\ *Corresponding author: antar.venus@unpad.ac.id
}

\section{ABSTRACT}

Introduction: Statistics shows that until 2015 around 25 $\%$ of the Riau people are still living in poverty. Two possible causes are the poor's lack of local access to financial institutions and low capability to solve poverty. Riau provincial government has introduced a community-based microfinance institution called Village Empowerment Program which includes economic empowerment, to be organized by local people. To ensure that the new local institutions are effective and community empowerment is achieved, the government appointed pendamping desa (village mentor). This study aims to understand the role of pendamping desa in empowering local community and institutions through communication approach.

Method: This research focuses on four different parts in Riau province. Data were collected through interviews with six informants who directly involved with the UED-SP program.

Results: Pendamping Desa are university graduates who are recommended by village leaders to be selected, appointed, trained by the provincial government and placed in areas close to their areas of origin. Communication skills of pendamping desa becomes the most important factor in improving community acceptance and in implementing community empowerment, and they also became a bridge between elements of society and simultaneously drives the various activities to increase the capability of local communities and institution. A participatory approach is the most suitable technique in empowering community and building the UED-SP institution.
Conclusion: Communication skill of pendamping desa plays a significant role in connecting all parties involved in community empowerment activities.

Keywords-Pendamping desa, UED-SP, community empowerment, Communication skill, and community leader.

\section{INTRODUCTION}

The number of poor people in Riau province is relatively large spread in pockets of poverty in coastal areas, river, islands and isolated rural areas. According to BPS (Indonesia Statistic Central Berrau) data, measured by the standard of living of US\$1per capita/day, in 2012 the percentage of poor people in Riau province is $11.20 \%$. If the standard of living is increased to US\$2/day, it the doubles to $25 \%$.

In relation, the province of Riau Government subsequently launched Program Pemberdayaan Desa (Village Empowerment Program) which is based on three pillars, namely community empowerment, economic development, and institutional capacity building. Of the three pillars the main focus is attached to the economic development aspect. The idea is when the level of social welfare has improved, the community may then begin to pay attention on improving their capacity, including developing institutional capacity building in their village.

The villagers economic condition in this program is improved by using the concept of UED-SP (Usaha Ekonomi Desa-Simpan Pinjam or Rural Economic 
Enterprise-Savings and Loans). UED-SP is a community-based microfinance program which is established and run by the locals. This program was first introduced in 1998 by the Ministry of Home Affair of the Republic of Indonesia on the efforts to overcome the impact of monetary crisis in 1998.

Riau Province Government adapted this program as it is deemed realistic in poverty reduction. Before adapted the UED-SP program, the Riau province government has carried out several poverty reduction programs proposed by the central government such as Urban Poverty Program (UPP), Subsidized Rice ((Raskin), Public Health Insurance (Jamkesmas), Aspiring Family Program (PKH), People Direct Aid (BLT), Farmer Business Credit (KUT), and also National Self Reliant People's EmpowermantProgram (PNPM Mandiri).

It seems that all of these programs fail to empower communities and reduce poverty in Riau province (and Indonesia in general), the UED-SP is no different. If the Riau provincial government simply execute this program without adaptation, innovation and visions of sustainable rural economic development, the program may also fail. However, the Riau province government instructed that the establishment of the UED-SP should be proposed and then developed by local community - the reason this institution is categorized as local institution.

One of the factors determining the success of the UEDSP in Riau province is the element of Pendamping Desa (PD) or Village Mentor that serves as a liaison, problem solver, motivator, mediator, and facilitator of the UEDSP program implementation.

The existence of PD is a prerequisite of the establisment of UED-SP in every village. The provincial government first provides the opportunity for residents of each village or from other villages in the same area to be a PD through an open recruitment process. After PD is selected and then trained for two weeks in the city of Pekanbaru (the capital of Riau Province), then the PD begin to facilitate the formation of UED-SP program in the village they represent. Within eight years, the Riau province government has generated 632 PD (Table1).

Table 1.

Number of Pendamping desa in Riau province Per 1 May 2014

PD, according to Levna Ervan (Deputy of Village Economic Empowerment in the Provincial Office of
People Empowerment and Village development), is an essential aspect in the success of the UED-SP Program in Riau province. They became an intermediary that connects the provincial and district government that develop the villages. Ikhfa Ravi/IR (head of project officer) states that PD can be considered as determinants of sustainability programs. Without the presence of PD, this program will most likely fail because the goverment do not able to monitor the execution of the program directly.

PD is one of those terms that is popular in many villages in the province of Riau. However, no research has been done to explore their roles. Yet they are the ones who contributed to develop the ability of rural communities in entrepreneurship and become the leaders driving the success of UED-SP

Given the importance and strategic role of $\mathrm{PD}$ in implementing UED-SP program, it is important to explore how PD are carrying out its role in the field. More specifically, this paper research aims to answer the following research questions. First, how do PD is selected and prepared for their positions? Second, what is the role and function of PD in the UED-SP program? Third, how does capable community manager will have impact on the success of local improvement capabilities project? Fourth and fifth, what are the obstacles they face and how do they overcome these obstacles?

This paper aims to provide the basic ideas of PD and their role in the success of UED-SP program in Riau province. This paper is important because this information may be useful for other parts in Indonesia that are also struggling in alleviating poverty.

\section{METHOD}

This study uses a descriptive case study method. The method is intended to describe and explore an event, person or stategy in depth by using quantitave and qualitative data. According to Cresswell (2002) and Yin (2012), a case study is an exploration of a bounded system or a case (multiple) overtime through detailed in depth data collection, involving multiple sources of information in rich context.

Data is collected through indepth interviews and document analysis. Interviews were conducted with reference to five research questions as mentioned earlier. These interviews were conducted for three days $\left(3^{\text {rd }}\right.$ and $4^{\text {th }}$ of May, and $2^{\text {nd }}$ of June 2014). 
Interview were conducted for four PD informants representing four different regions in the province of Riau, namely TY (from Pekanbaru Village), RZ (Bengkalis), DH (Pelalawan) and HS (Indragiri Hilir). Each PD has served in that position for at least three years, thus they have a good understanding and broad experience in the field of developing UED-SP program. In addition, Levna Ervan/LE (Deputy of village economic empowerment in provincial office of people empowerme and Village development), and Ikhfa Ravi/IR (head of project officer) we also interviewed.

\section{RESULT}

Based on the results of data collected through interviews and document analysis, we able to provide answers to the previous research questions as follow.

\section{1) How do PD is selected and prepared for their position?}

PD are people chosen from a selection of processes conducted openly. According to IR, selection should be open because the government wanted to obtain the best candidate who are capable of helping the government to reduce poverty through community-based microfinance activities for rural people. PD will become managers to synergize and optimize local resources in empowering local communities and local agencies so that they can solve their poverty problems. IR also stated the reason why pendamping Desa shoud be local people. The Government expect the Pendamping Desa can easily accepted by local community and adapt themselves with local norm, values and habit. By being accepted by local people the opportunity to cooperate and persuade local people to involve in the UED-SP project increase.

Based on the explanation of $\mathrm{LE}^{1}$, it can be deduced that the recruitment of PD must consider both parties to be bridged by this officer. For this reason, PD should be recruited from people who live in or around the village that will be represented. Where possible, the recommendations of formal or informal leaders in the village could be required.

2) What is the role and task of PD in the UED-SP program?

\footnotetext{
${ }^{1}$ Interview with LE, 3 May 2014
}

According to $\mathrm{IR}^{2}$, although the role of $\mathrm{PD}$ focuses on economic aspects of rural development, they do the task that is much broader than its main task. They help make the planning and development of the region and help realize the implementation of village development programs. This role comprises of twenty-eight tasks which, according to RZ, can be grouped into five aspects, namely, facilitating the UED-SP manager, helping to overcome various problems in a village, connecting the village development plan with various relevant agencies, monitor the implementation of the UED-SP program, and explore and map the problems of the village and communicate it to the BPM-Bangdes (the Board of community empowerment and Rural Development).

All informants, on the basis of their experience and prolonged engagement with UED-SP program, said that the role of $\mathrm{PD}$, in principle, may be grouped into five categories, i.e facilitator, integrator, investigator, communicator, and problem solver. Related to these roles, $\mathrm{H}$ from Indragiri Hilir says;

"PD must have a lot of energy, because of various problems related to the implementation and development of UED-SP will ultimately involve us ... so we must always be ready to assist, encourage, persuade, and solve the problems faced by the managers of UED-SP.... $P D$ also should share information or 'success stories' of UED-SP beneficiaries through word of mouth, and also short Messages Service, and other channels"

While Informant $\mathrm{H}^{3}$ states that PD must be able to put himself proportionally and correctly between the position of government representative and as a village development facilitator, informant $\mathrm{H}$ statement shows that $\mathrm{PD}$ has to become a bridge and a catalyst in overcoming various related rural development problems.

As a liaison officer between the government and the village they represent, PD must be able to understand both parties. PD must be able to put himself/herslef in the triangular interaction. They must also have other skills that will support the implementation of their duties, which includes: technical capabilities of microfinance institutions management, communication and negotiating skills, administrative management capability, and ability to solve problems and make

\footnotetext{
${ }^{2}$ Interview with IR/2 June 2014

${ }^{3}$ Intervie with H/3 May 2014
} 
decisions. In general, PD obtained this capability through training that has been followed.

In performing its role as facilitator, PD strives to encourage and assist UED SP managers in improving their ability and professionalism in managing these institutions. Related to this $\mathrm{TY}^{4}$ and $\mathrm{RZ}^{5}$ states;

"We have to monitor for twenty-four hours this UED-SP institutions to ensure they are properly managed. For every problem, we always find the solution together with the manager. We also often proactively track and monitor the management of this institution to the community and community leaders to ensure that all the inhibiting factors can be detected as early as possible and look for solutions."(TY)

"In managing UED SP in my opinion the most important thing is to ensure administrative system running well, the borrower actually selected on the basis of the requirements set, in collaboration with village leaders, informal leaders, and managers UED SP ... Do not allow any slightest problem because it would trigger the emergence of a larger problem. Report any developments that occur regularly to the Regional Coordinator." $(R Z)$

Cooperation and communication with local leaders is an important part in the management of UED-SP program. Involving the local leaders in the board of UED-SP management can result in having support from them when PD needs help in handling problem related with UED-SP.

(3) How does capable community manager will have impact on the success of local improvement capabilities project?

PD who successfully perform their tasks in community empowerment and strengthening of the institutional aspects UED-SP are usually those who were able to communicate well with a variety of formal and informal leaders and society.

In this context, communication is not only viewed from the aspect of the frequency and breadth of PD's network, but also on how PD can adapt to the culture, values, and can communicate with the local community. The

\footnotetext{
${ }^{4}$ Interview with TY/4 May 2014

${ }^{5}$ Interview with RZ/3 May 2014
}

successful PD is also a person who is able to build a personal relationship with various public figures and be able to understand the problems faced by the community.

According to R, TY, and DH, communication skills of is the main factor that make them acceptable to the local community and then able to work together with the local community to improve their ability to develop UED-SP program and changing the behavior of local people in entrepreneurship. The knowledge and skills of the UEDSP managers can be increased with the problem-solving oriented approach.

IR as the head project manager also mentioned that the communication approach is one of the significant factors that contributed to the successful implementation of the UED-SP program in Riau province. That is the reason why the board of community empowerment and rural development (BPM-Bandges) is responsible for training programs equip $\mathrm{PD}$ with the communication skills that are practical, as well as with the ability to manage communication conflict.

\section{(4) What are the obstacles they face?}

TY, R, H, DH stated that they deal with no small challenges. However, accumulated experience over the years made them more capable in managing any issues that arise. In this regard, the informants $\mathrm{TY}^{6}, \mathrm{DH}^{7}$, and $\mathrm{RZ}^{8}$ states as follows;

"Well, I face many problems during my first year as $P D$," starting from overdue payments, the hostility of the local opinion leaders of whom the loan were rejected, until the intervention of the village head in determining beneficieries." (TY)

"I think the UED-SP management problems are almost the same in every region. This problem is usually associated with overdue payments, UED-SP officer who can not use computers, no electricity, the absence of (letter of) guarantee, forcing to get loans, and so on. In several regions we also face dishonesty of some managers." $(R Z)$

From the description of the informants, we found as many as twenty kinds of problems typically faced by PD (Table 2).

\footnotetext{
${ }^{6}$ Interview with TY/op.cit

${ }^{7}$ Interview with DH/ May 2014.

${ }^{8}$ Interview with RZ/3 May 2014
} 
Table 2

Problems of $P D$ in facilitating UED-SP Program

\section{(5) How do they overcome these obstacles?}

Through the forum 'companion village' and also in consultation with the coordinator of the city/county, PD has developed various systems and techniques of handling the problem. According to $\mathrm{TY}^{9}, \mathrm{R}^{10}$, and $\mathrm{H}$ the techniques that they developed are generally good and so far it can overcome various problems. In this regard, the informant made the following comments;

"To overcome the issues of payment and also intervention of village leaders, I usually do heart to heart communication (relationship)..., aside of the standard operating procedure agreed by local people through village meeting, we also announce the name of beneficiaries with delinquent payment through the speaker of Mosque during Jumat praying. "(TY)

"I use formal and informal procedures. I wear a formal warning letter (to the beneficiaries with delinquent payment), reported the problems that arise to the area coordinator if you cannot handle it alone...I also build strong communication with local leader. " $(H)$

The data above shows that PD have learned from the accumulated years of experiences to overcome common problems that arise in empowering local people and the management staff of UED-SP.

\section{DISCUSSION}

Based on all the previous description, it seems that PD indeed has a very strategic role in developing UED-SP program in the province of Riau.

The success of the UED-SP program in Riau province may be directly related to the ability of PD in promoting motivation to change the poor's condition, equip them with the information and skills necessary to run a business, and persuade the public and UED-SP management staff to work according to existing rules. In addition, the PD's ability to resolve conflicts and making decision democratically become an important capital in building synergies with leaders and local communities. This is in line with the concept of participatory communication developed by Tufte and Mefalopulos

\footnotetext{
${ }^{9}$ Interview with TY/op.cit
}

${ }^{10}$ Interview with $\mathrm{H} / \mathrm{op} / \mathrm{cit}$
(2009) which states that the community empowerment is more successful with a dialogical approach, in which they define their problems, identify available resources, to take decisions and implement them together.

The three aspects that are emphasized by the government, namely the establishment of UED-SP as the initiatives of local communities, the appointment of PD as a bridge between the various parties, and the communication approach emphasized by the government in the implementation of the work and the settlement of various issues that arise, give a great influence on the success of the program UED -SP in Riau province.

This study is still a preliminary exploration. There are still many aspects that are untapped in this study such as how to manage conflict in the UED-SP group decision making or how PD build openness among the management teams of UED-SP. Various findings of this research will also be very interesting when analyzed by interpretive theory (symbolic interactionism), narrative (fantasy theme analysis), or positivistic (groupthink theory). The use of these theories as a framework for further research will enrich our understanding of the phenomenon of PD not only in Riau province but also in various places in Indonesia that use similar approach.

\section{CONCLUDING REMARK}

$\mathrm{PD}$ is a community manager that is appointed and trained by the provincial government to be a facilitator in building the entrepreneurial capacity of rural communities while developing professionalism of the managers in the management of the UED-SP. This study shows that the PD who are successful in running their duties as community manager are those who have a broad knowledge of UED-SP program, committed in providing assistance and have good communication skills.

The communication skills in practice become a bridge connecting the various elements of society (stakeholders) and in turn is able to synergize the various local resources to empower rural communities and institutional aspects of existing UED-SP. Communication also become the crucial factors in the sustainability of UED-SP program.

Conflict of interest: none declared.

ACKNOWLEDGEMENT 
The authors would like to thank Mr. Levna Ervan, Mr. Ikhfa Rafi , and Mr. Rusli as senior PD who at the same time connects me with other PD who became informants in this study.

\section{REFERENCES}

Creswell, John W. Qualitative Inquiry and Research Design. Sage Publication, Thousand Oaks , 2002.

Depdagri. Peraturan Menteri Dalam Negeri No 6 tahun 1998.

Pedoman Umum Program Pemberdayaan Desa (PPD) Propinsi Riau. oleh: Tim Koordinasi P4D Propinsi Riau tahun 2006. Pekanbaru.2006.

Rusli, et.al. Pemberdayaan masyarakat Miskin melalui Program Usaha Ekonomi Desa-Simpan Pinjam (UED-SP). Jurnal kebijakan Publik. Vol 3 ed. 22012

Rusli. Menggerakkan Ekonomi Rakyat. :Implementasi Program emberdayaan Desa (PPD) di kapubaten Indragiri Hilir. Alafriau, Pekanbaru, 2012.

Table 1. Number of Pendamping desa in Riau province per 1 May 2014

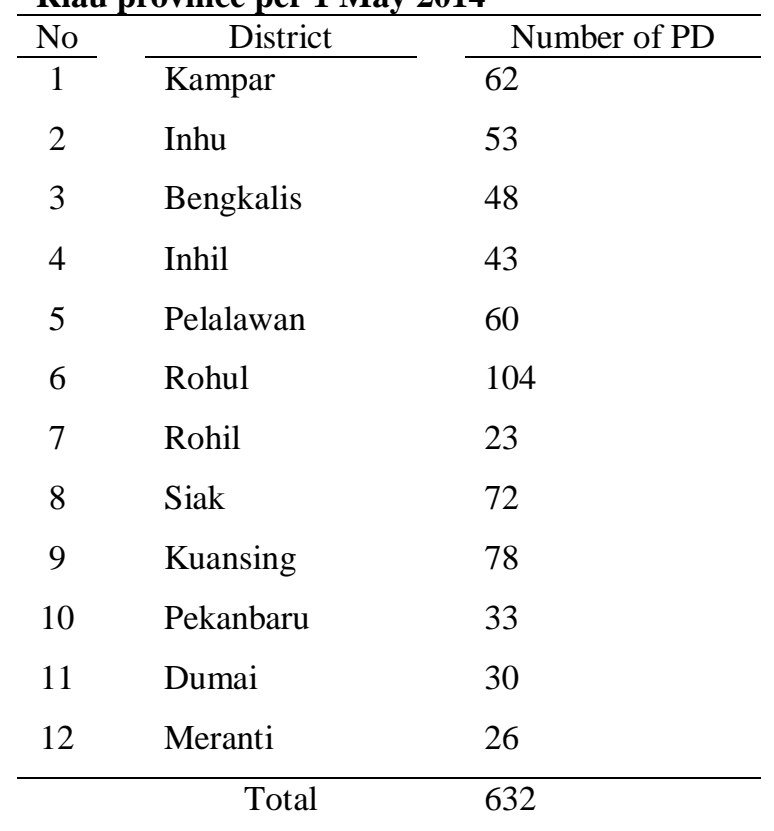

Source: author construct
Stake, Robert E. The Art of Case Study Research. Sage Publications, Thousand Oaks, CA, 1995.

Sumantoro Martowijoyo. Indonesian microfinance at the crossroads : caught between popular and populist policies. Through

http://www.microfinancegateway.org/gm/documentaccesed 21 june 2014

Tim kerja UED-SP. Manajemen adminitrasi UED-SP Olang Pulang. Pangian Kuantan Singigi, 2012

Tufte, Thomas \& Paulo Mefalopulos. Participatory Communication. Wahington DC. The World bank. 2009.

Usman, Sunyoto. Pembangunan dan Pemberdayaan Masyarakat, Pustaka Pelajar: Yogyakarta: 2013

Yin, Robert K. Case Study Research, Design and Methods, 3rd ed. Sage Publcations, Newbury Park, 2002. 
Table 2. Problems of PD in facilitating UED-SP Program

\begin{tabular}{|c|c|}
\hline No & Problem \\
\hline 1 & Village Leaders' intervention in determining the borrower and the amount of the loan \\
\hline 2 & Local people consider the loans as charity \\
\hline 3 & The unavailability of electricity and computer \\
\hline 4 & Poor understanding of village officials about UED-SP \\
\hline 5 & Lack of budget funds \\
\hline 6 & Low performance management \\
\hline 7 & Payments issues \\
\hline 8 & Negotiating for those who refuse to pay \\
\hline 9 & Difficulties in teaching cashier create an orderly financial statements \\
\hline 10 & Difficulties in teaching beneficieries in creating simple business records \\
\hline 12 & Managers who borrow without procedure \\
\hline 13 & unopennes and Dishonesty of UED-SP officer \\
\hline 14 & The low quality of local human resources \\
\hline 15 & Angry when loan amount is lowered \\
\hline 16 & Beneficiaries lobbying privately to PD \\
\hline 17 & Low commitment of villlage office staff \\
\hline 18 & Postponing job fulfilment \\
\hline 19 & Speaking very rude \\
\hline 20 & Beneficieries break the rules/contract. \\
\hline
\end{tabular}

Source: author construct 